Poa bulbosa, and Fragaria vesca. There are also the following common grasses with foliage emerging in spring: Themeda anathera, Chrysopogon echinulatus, Stipa sibirica, Oryzopsis munroi, Poa angustifolia, and P. bulbosa.

Summer (June to August): Saussurea albescens, Heracleum candicans, Dipsacus mitis, Geranium wallichianum, Nepata spicata, $N$. linearis, Lavatera kashmiriana, Phlomis spectabilis, Delphinium incanum, Agrimonia eupatoria, Geum urbanum, Cannabis sativa, Setaria viridis, and Pennisetum flaccidum.

Autumn (September to November): Artemisia vestita, A. japonica, Themeda anathera, Chrysopogon echinulatus, Polygonum plebeium, Solanum nigrum, and Fagopyrum cymosum.

Winter (December to February): There is not much palatable vegetation available in Dachigam Sanctuary in winter, though a few species in leaf (useful as fodder) can be met with. The list is in order of decreasing abundance-Plantago lanceolata, Viola odorata, V. sylvatica, V. falconeri, Gagea elegans, G. kashmirensis, Colchicum luteum (abundant in February-March), Arabis amplexicaulis, A. auriculata, Drabopsis nuda, Poa annua, P. pratensis, Taraxacum offi- cinale, Capsella bursa-pastoris, Fragaria vesca, Carex setigera var. schlagintweitiana, Bergenia ciliata, Corydalis diphylla, and Fritillaria imperialis.

The Dachigam Sanctuary and the adjacent valleys in the Vale of Kashmir constitute the last reserve of the Hangul. To save this magnificient animal for posterity, Kashmir can still boast an excellent habitat. Now that the ecological inventory of the characteristic floristic elements has been made, the hopes of the legion of Indian naturalists to save the Hangul from its endangered status have brightened considerably. The floristic elements of Dachigam have a close relationship to the presence of the Hangul, whose habitat consequently needs conservation. The undesirable human disturbances must cease.

The author wishes to thank particularly Dr Gurcharan Singh, formerly of Kashmir University but now at Khalsa College, New Delhi, for his kind help in the determination of the plant species.

G. M. OzA

General Education Centre

Maharaja Sayajirao University of Baroda Baroda 390 002, India.

\title{
Thailand Urged to Reconsider Dam Project
}

The World Wildlife Fund and the International Union for Conservation of Nature and Natural Resources have urged the government of Thailand to reconsider plans for four irrigation dams in the vicinity of the Khao Yai National Park, 200 kilometres north-west of Bangkok, because of the inherent dangers to the environment.

The two organizations indicated that, although technical surveys had been carried out, no environmental impact study had yet been undertaken. Their joint letter to the Government of Thailand said in part: 'We are greatly concerned that the construction of four irrigation dams at Khao Yai cannot but have serious adverse effects on the National Park and the surrounding areas. Large areas of rain-forest and deciduous mountain forest will be flooded to the extent that the eastern part of the Park, containing the only significant rain-forest area left in Thailand, will lose its value as a conservation area.

'The Khao Yai forest has an important natural function as a regulator of the water budget of the surrounding agricul- tural plains, and it is doubtful whether artificial lakes will provide better regulation of water outflow than the natural undisturbed forest. Furthermore, the run-off of water during the rainy season could be considerably accelerated by loss of the forest, causing an increased risk of flooding surrounding farmland. In addition, artificial water reservoirs, and the increased water-flow to be expected in wet seasons, may cause serious problems of erosion as some of the areas affected are steep valleys.'

The letter pointed out that the project had apparently been abandoned four years ago after the attention of the Government had been drawn to the dangers involved, and there was now 'considerable concern' at the revival of the project. IUCN and WWF accordingly offered their assistance in obtaining an environmental impact study.

\section{Peter F. R. JACKson, Director of Information World Wildlife Fund 1110 Morges, Switzerland.}

\section{New Method of Monitoring Earth's Upper Atmosphere}

A new 'tool' which can routinely monitor the chemicals and pollution-level if part of the Earth's atmosphere that was only intermitter tly observable before, has been developed by astronomers from Harvard College Observatory and the Smithsonian Astrophysical Observatory. Using an earth-based radio telescope especially intrumented to observe water vapour in remote parts of our Milky Way galaxy, the astronomers reported that they have detected and measured water vapour at high levels in the Earth's atmosphere, actually finding 'surprising amounts'-as much as 15 parts per million-at altitudes between 50 and 80 kilometres ( 30 to 50 miles) in a region known as the mesosphere. This is well above the 10-kilometres level reached by conventional weather balloons.

The discovery was made by a team of scientists that included Dr Harrison E. Radford, Dr Marvin Litvak, Drs Carl and Elaine Gottlieb, Shoshana Rosenthal, and Dr Edward Lilley. They reported their findings to the National Science Foundation's Division of Atmospheric Sciences, which funded part of the research. The scientists' observations, made with the 120-feet (ca 36.6-m) diameter radio telescope at the Haystack Observatory of the North- east Radio Observatory Corporation in Westford, Massachusetts, probed heights that otherwise would have required expensive techniques such as rockets.

'This new discovery should prove useful in keeping track of an important constituent of the upper atmosphere', Dr Radford said: 'Using the techniques of radio astronomy, scientists should now be able to measure routinely the concentration of water vapour, as well as other molecules, high in the atmosphere.'

The new measurements indicate a water-vapour content about $50 \%$ higher than was expected from theoretical models of the atmosphere. However, it appears that the concentration of water at the high altitudes probed in these observations may vary from time to time, and further measurements will be required to establish the pattern. Meanwhile, details of the research results have been published in the space physics issue of the Journal of Geophysical Research.

\section{RALPH KAZARIAN National Science Foundation $1800 \mathrm{G}$ Street, Washington D.C. 20550, U.S.A}

